\title{
Political Party Financing and Consolidation of Democracy in Nigeria, 1999 - 2015
}

\author{
Dr Ejikeme Jombo Nwagwu
}

\begin{abstract}
Political parties and elections constitutionally give democracy legitimacy, credibility and general acceptance as essential elements of pluralistic democracies. Parties are political framework under which platform people of like minds converge to articulate ideas and best strategies to canvass for public support to compete and possibly capture state power through elections. As democracy is capital intensive, political parties cannot thrive without funds, and supportive finance is hard to generate for its statutory functions without external aids and viability of its membership. Sourcing money for political party business beyond the approved limit has derailed politics and weakened the course of democracy in Nigeria. Excessive financing of political parties for their statutory functions and elaborate electioneering campaign programmes, and limitless expenses incurred in sponsoring candidates for elective public offices, have degenerated political parties to auction sales to the highest bidder among political entrepreneurs. The party is therefore being mortgaged as political collateral for the huge investments by political investors. The objective of the study is to investigate political parties and candidates excessive financing; and its effect in consolidating democracy in Nigeria. Ex-post facto research design is adopted, and elite theory is adopted to explain the adverse role of plutocracy in consolidation of democracy.
\end{abstract}

Keywords: Democracy, Political Party, Finance, State Power, Good Governance

\section{INTRODUCTION}

The anatomy of democracy posits political parties and elections as the blood vessels of the system, while the Constitution of a sovereign democratic state is the heart pumping political blood into the system to re-enforce and energize the components for effective performance. Political parties and elections are the bridge linking the populace to the activities of the government. They are the energetic elements that constitutionally give democracy legitimacy, credibility and general acceptance as essential ingredients to pluralistic democracies. Political parties are the structural framework under which platform people of like minds converge to articulate ideas and best approaches to canvass for public support to compete and possibly capture state power through elections. Democracy is a capital intensive venture, and political parties cannot thrive effectively in the arena without sufficient funds. Supportive finance would be hard to generate for its statutory functions without external aids and viability of its membership. Cole (2016)[1] notes that Nigeria practices one of the most expensive political systems in the world. Finance has been the major bane in the development of the country's political system, as there is no effective laws, or culture, or strong institutional regulatory framework about how to finance political parties or the limit of expenses on elections, and sources of such finances. A salient aspect of the electoral reform to rejuvenate the political system is the provision to record the entire cost of running individual parties activities, sources of such finances (names and addresses of donors), and detailed logistic expenses on the electioneering campaigns (e.g. domestic rallies, external forums, radio, television, and newspaper advertisements or jingles, customized textiles, posters, billboards, transportation facilities, hotel accommodations, etc) as obtainable in advance democracies.

Democracy is considered a viable system of government controlled by the people on equal footing. Practically, unequal access to resources to foot political bills, and unregulated campaign financing have created uneven political playing ground in Nigeria. Excess access of funds jeopardizes the tenets of democracy, gives undue advantage to wealthiest parties and their imposed candidates over others who are financially weak to execute their political projects. In Nigeria, money speaks louder than promising service-oriented, viable and competent contenders, it makes swift changes, and guarantees the holder success in the party primaries and the general poll. The poor are easily influenced with a pinch of salt or a grain of rice to change their political behaviour. Incredible range of discrepancies in 
levels of funding parties and individual candidates, disenfranchise many of the financially weak opponents, and frustrates the efforts of challengers in the political competition. Most often, government apparatuses (law enforcement agencies and state finances) are being deployed by incumbent state officials as readily available political tools to intimidate and overrun opponents. The abuse of state resources threatens Nigeria's effective governance and its inclusive democracy. Financial involvement in obtaining political nomination forms for elective public offices is astronomically higher and beyond the reach of average political aspirant. This high bid system of financing is a systemic instrument being used to ward-off financially weak-based politicians. Sourcing money for political party business beyond the approved limit has derailed politics and weakened the course of democracy (http://nairaproject.com/projects/923.html).[2] There is ongoing debate on the theme that excessive illicit financing of political parties and massively corrupt financial support of individual candidates on electoral competitions constitute serious threat to the process, and negatively influence the development of politics and consolidation of democracy in developing countries.

Against this background, the objective of the study is to investigate whether political parties are excessively financed; and to ascertain whether unregulated sponsorship of individual candidates by political entrepreneurs undermines consolidation of democracy in Nigeria.

\section{DEFINITION OF CONCEPTS}

Political Party Funding: This refers to the set of methods that a political party applies to raise money for campaign and other routine activities. Political parties require sufficient financial resources to perform their functions. Money is the oil that lubricates party machinery. Funds for party activities (either for routine operations or campaign programmes) can be solicited through grassroots fundraising from party membership or individual supporters through payment of dues, fees, subscriptions. and small donations; voluntary contributions from individuals (e.g. direct mail fundraising); parties can resort to non-monetary resources in the form of access to state premises, media and/or vehicles that are often made available for political activities, and this can afford valuable contributions to parties' abilities to organize themselves as against plutocratic funding or the business community as corporate donations. Similarly, organizations which share their political views (e.g. trade union affiliation fees) or which can benefit from their activities (e.g. corporate donations), or taxpayers contribution are identified. The general revenue fund by grants called state aid, government or public funding are also sources. These are fundraising exercise in support of political party activities, campaigns, and individual candidates for elective public offices (https://en.wikipedia.org/ wiki/political_party_funding). [3]

Political Party: A political party is an aggregate of people united by a common and collective desire to capture political power and authority within a legitimate and legal political framework, by canvassing for votes in a democratic polity. It is an organization of people with the aim of seeking and gaining political power in order to realize certain common objectives of the members. These organizations mobilize voters on behalf of a common set of interests, concerns, and goals. Political parties play crucial roles in the democratic process through formulation of political and policy agenda, selection of candidates, conduct election campaigns, and monitor the activities of their elected representatives to rhyme with the party manifesto. Magolowondo et. al (2012)[4] observe that it is almost inconceivable to have a functioning democracy without political parties. Political parties can and do serve a wide variety of functions such as aggregating and articulating interests, developing competing policy proposals that provide voice and choice, selecting candidates for elected office, organizing legislatures, coordinating the formation and activities of government, recruiting and linking leaders and supporters and conducting electoral campaigns. Political parties link citizens and the government, providing means by which people can have their voice heard in government of their country.

\section{Methodology}

The researcher adopted ex-post facto research design for the study. Qualitative method of data collection was applied to elicit information from documentary evidence of secondary source. This method is considered appropriate tool to collect data because the events had taken place before the study, and the elements cannot be changed or influenced by the researcher. Ali (2006) [5] notes that casual comparative studies describe how an event that is not manipulated has probable impact on another event. Nworgu (2006) [6] observes that in ex-post facto design, the researcher attempts to link 
some already existing effects or observation to some variables as causative agents. At the commencement of the study, the researcher finds that the subjects are already assigned to or classified into various levels of the variables whose effects are being investigated and he cannot alter the situation, rather he deals with independent variables that cannot be manipulated. Umar (2016) [7] notes that a qualitative approach emphasizes the qualities of entities, processes and meanings that are not experimentally examined or measured in terms of quantity, amount, intensity or frequency. The research design is adopted on this basis.

\section{TheORETICAL FraMEWORK}

The study adopted elite theory. This theory explains the roles of the elite class in influencing the political party processes with intimidating, uncontrollable, and limitless financial resource in financing party activities, campaign programmes, and sponsoring contenders. In the field of political science and sociology, scholars define elite theory as a theory of the state which seeks to describe and explain the power relations in contemporary society. The theory holds that a small minority, consisting of members of the economic elite and policy-planning networks, possesses most power and that this power is independent of a state's democratic election processes. Through positions in corporations, on corporate boards, and influence over the policy-planning networks through financial support of foundations or other positions with "think-tanks" or "policy-discussion groups", members of the elite are able to exert significant power over the policy decisions of corporations and governments (http://en.wikipedia.org/wiki/Elite). [8]

The exponents of the theory of political elites, which came under active debate amongst the social scientists in the fifties, such as Schumpeter (economist), Lasswell (Political Scientist), and C. Wright Mills (Sociologist) traced their history back to the writings of a number of European philosophers in the year preceding the growth of fascism, particularly to Vilfredo Pareto and Gaetano Mosca (both Italians), Roberto Michels, a Swiss German and Jose Ortega Y. Gasset, a Spaniard. It is Pareto's (1848-1923) belief that every society is ruled by a minority that possesses the qualities necessary for its accession to full social and political power. The theory argues that those who get on top are always the best, and they are known as the elite. Roberto Michels (Sociologist) developed the Iron Law of Oligarchy where, he argued, social and political organizations are run by few individuals, and social organizations and labour divisions are key indicators. Michels believed that all organizations were elitist and that elites have three basic principles that help in the bureaucratic structure of political organization; and these include the need for leaders, specialized staff and facilities; utilization of facilities by leaders within their organization; and the importance of the psychological attributes of the leaders. Freeman (n.d) [9] notes that the over-structured society we found ourselves, and the inevitable control this gave others over our lives, and the continual elitism of the left and similar groups among those who were supposedly fighting this over structured ness is for the interest of the elite class that skewed the society.

The elite theory was based on the idea that every society consists of two broad categories - the selected few, who are capable, therefore, have the right to supreme leadership as against the vast masses of people who are destined to be ruled. This theory, according to Varma (1975), [10] originated in Central and Western European countries as a critique of democracy and socialism. It was adopted by scholars to explain political processes as they are practiced in democratic countries. The theory posits that within those who constitute the ruling class, including ruling elite, there exist a counter-elite, which could be raised to power by the masses if the ruling elite loses its power and capacity to rule. In other words, the masses manipulate the ruling elite, but they could not be expected to exercise enormous positive influence due to their apathy to the power game. As soon as it was established that the elite must not be cohesive group, therefore, it could consist of other social groups as the exponents of group theory contended, it comes to bear that every society consists large number of groups that engaged in perpetual struggle for power and domination over each other. The struggle involved a process of balancing and limiting each other to maintain social harmony between the various interest groups in society (http://en.wikipadia.org/wiki/Elite_theory\#Classical_elite_ theorists). [11]

The elite theory has aroused sound intellectual debates amongst scholars of different perspectives. The theoretical view held by many social scientists which holds that American and European politics is best understood through the generalization that nearly all political power is held by a relatively small and wealthy group of people sharing similar values and interests and mostly coming from 
relatively similar privileged backgrounds. Most of the top leaders in all or nearly all key sectors of society are seen as recruited from this same social group, and elite theorists emphasize the degree to which interlocking corporate and foundation directorates, old school ties and frequent social interaction tend to link together and facilitate coordination between the top leaders in business, government, civic organizations, educational and cultural establishments and the mass media (http://en.wikipedia.org/wiki/Elite). [12] The application of this theory to the study illustrates how Nigeria polity is elitists in nature and character. How plutocrats dominate the political processes and dictate the pace of political degeneration and underdevelopment in the country.

\section{Regulating Political Party Financing}

Financing political party for its functions and sponsoring election campaigns is vital in a vibrant democracy. Ballington et.al (2014) [13] note that regular elections organized between competing political parties is the dominant method of selecting democratic governments. For political parties and their nominees to reach out to the teaming electorates to sell the parties manifestoes, it becomes imperative to have access to enough money so as to off-set election expenses. Election expenses, according to Electoral Act 2010, [14] means "expenses incurred by a political party within the period from the date notice is given by the Commission to conduct an election up to and including the polling day in respect of the particular election". Magolowondo et al (2012) [15] note that parties may win or lose elections well before they are held simply on account of their resource endowment or lack thereof. In other instances, how parties practice or fail to practice intra-party democracy has to some extent been influenced by the way they are financed and how these resources are allocated within the different parties. The concern for possible negative impact of money on politics and governance warranted the incorporation of the regulatory clause in the 1999 Constitution and the 2010 Electoral Act of the Federal Republic of Nigeria to curb the excesses and unregulated donations to political parties and individual candidates which breeds corruption. Money exercises undue influence on politics, and undermines the integrity of elections, credibility and legitimacy of government.

In the first republic (1960-1966), there was indefinite electoral law on campaign finance. Funding election activities and other political parties' functions were the responsibility of the individual parties and their candidates. From knowledge of hindsight, there were political parties who were accused to have used the state funds and investments to sponsor party activities and campaigns, such as the National Council of Nigeria Citizens (NCNC) and Action Group (AG). The 1979 Constitution of the second republic (1979-1983) provided regulatory law on campaign finance which prohibited associations, other than political parties, from campaigning on behalf of a candidate or contributing funds to parties and election expenses of candidates. There was the budgetary provision for annual grants to political parties; and political parties were empowered to receive donations from individuals and corporate bodies, but it prohibited donations from external bodies. The unquantifiable partydonations from individuals and corporate bodies, and unprecedented expenses incurred on party activities and campaigns due to the fact that the limit of funds political parties and aspirants could raise from individuals and corporate bodies was not specified by law. The prevalent corrupt practices, electoral irregularities, and uncordial interparty relations in the second republic amongst the National Party of Nigeria, Nigerian Peoples Party, Unity party of Nigeria, Great Nigerian Peoples Party, People Redemption Party, etc. breached the provisions of subsisting Constitution and exacerbated party expenses. Political party antagonistic clashes, south-western zone post-election crisis, and increasing tension in the heated polity abruptly brought the republic to tragic end through military coup d'état.

Government in the fourth republic is not oblivious of the fact that politicians would abuse party financing if their activities are unregulated and unsupervised by electoral umpire. On the strength of the perceived dangerous threat to democracy, Section 221 of the 1999 Constitution of the Federal Republic of Nigeria provides that "no association, other than a political party, shall canvass for votes for any candidate at any election or contribute to the funds of any political party or to the election expenses of any candidate at any election". Section 225(2) stipulates that "every political party shall submit to the Independent National Electoral Commission (INEC) a detailed annual statement and analysis of its sources of funds and other assets together with a similar statement of its expenditure in such form as the Commission may require". 225(3) states that "no political party shall hold or possess any funds or other assets outside Nigeria; or be entitled to retain any funds or assets remitted or sent to it from outside Nigeria". Similarly, Section 225(4) provides that "any funds or other assets remitted or sent to a political party from outside Nigeria shall be paid over or transferred to the Commission 
within twenty-one days of its receipt with such information as the Commission may require"; while 225(5) stipulates that "the Commission shall have power to give directions to political parties regarding the books or records of financial transactions which they shall keep and, to examine all such books and records" (FRN, 1999). [16]

\section{Limitations on Nigeria's Election Expenses}

The fourth republic has witnessed enactment of Electoral Acts and subsequent amendments by the National Assembly to guide conduct of elections since the return of democracy in 1999. The Electoral Act of 2002 guided 2003 elections; 2006 Act (as amended) was used for 2007 elections; and 2010 Act (as amended) guided 2011 and 2015 general elections. The 2006 Act categorically provided funds limitations on campaign expenses to curtail the unhealthy influence of money on party activities and electioneering campaigns. Table 1 illustrates the stipulations. Section 90(1) of the 2010 Electoral Act provides that "the Commission shall have power to place limitation on the amount of money or other assets, which individual or group of persons can contribute to a political party". In the same manner, Section 91(2)-(7) states that:

the maximum election expenses to be incurred by a candidate at a Presidential election shall be one billion naira ( $\$ 1,000,000,000.00$ ); the maximum election expenses to be incurred by a candidate at a Governorship election shall be two hundred million naira ( $\$ 200,000,000.00$ ); the maximum amount of election expenses to be incurred in respect of Senatorial seat by a candidate at an election to the National Assembly shall be forty million naira ( $\$ 40,000,000.00$ ), while the seat for House of Representatives shall be ten million naira ( $\$ 10,000,000.00)$; in the case of State Assembly election, the maximum amount of election expenses to be incurred shall be ten million naira $(\$ 10,000,000.00)$; in the case of Chairmanship election to an Area Council, the maximum amount of election expenses to be incurred shall be ten million naira $(\mathrm{N} 10,000,000.00)$; in the case of Councillorship election to an Area Council, the maximum amount of election expenses to be incurred shall be one million naira (N1,000,000.00) (FRN, 2010). [17]

Subsection 91(9) provides that "no individual or other entity shall donate more than one million $(\mathrm{N} 1,000,000.00)$ " to either a political party or to a candidate. Subsection 91(10) states that a candidate who knowingly acts in contravention of this section commits an offence and on conviction shall be liable, in case of presidential election, to a maximum fine of $\$ 1,000,000.00$ or imprisonment of 12 months or both; in the case of a governorship election, to a fine of $\$ 800,000.00$ or imprisonment for 9 months or both; in the case of senatorial seat election in the National Assembly to a fine of \$600,000.00 or imprisonment for 6 months or both; in the case of House of Representatives election in the National Assembly to a fine of $\$ 500,000.00$ or imprisonment for 5 months or both; in the case of a State House of Assembly election to a fine of $\$ 300,000.00$ or 3 months imprisonment or both; in the case of Chairmanship election to a fine of $\mathrm{N} 300,000.00$ or 3 months imprisonment or both; in the case of Councillorship election to a fine of N100,000.00 or 1 month imprisonment or both (FRN, 2010). [18] The 2010 Act also made a provision in Section 93(1) that "no political party shall accept or keep in its possession any anonymous monetary or other contributions, gifts, properties, etc from any source whatsoever. Table 1 captures the provisions of 2006 Act and analysis on 2010 Act.

Table1. Legal Limit on Election Expenses

\begin{tabular}{|l|c|l|c|}
\hline 2006 Electoral Act & 2010 Electoral Act \\
\hline Office Position & $\begin{array}{l}\text { Approved Limit of } \\
\text { Expenses (N) }\end{array}$ & Office Position & $\begin{array}{l}\text { Approved Limit of } \\
\text { Expenses ( })\end{array}$ \\
\hline President & $500,000,000.00$ & President & $1,000,000,000.00$ \\
\hline Governorship & $100,000,000.00$ & Governorship & $200,000,000.00$ \\
\hline Senate & $20,000,000.00$ & Senate & $40,000,000.00$ \\
\hline House of Representatives & $10.000,000.00$ & House of Representatives & $20,000,000.00$ \\
\hline State Assembly & $5,000,000.00$ & State Assembly & $10,000,000.00$ \\
\hline LG Chairmanship & $5,000,000.00$ & LG Chairmanship & $10,000,000.00$ \\
\hline Councilors & $500,000.00$ & Councilors & $1,000,000.00$ \\
\hline
\end{tabular}

Source: Federal Republic of Nigeria Electoral Acts of 2006 and 2010 (Amended)

Monitoring election activities and ensuring strict compliance with the subsisting laws, electoral rules and regulations in democracy assist to facilitate democratic consolidation by instilling domestic and 
international legitimacy and credibility of the entire process. Lawlessness in party fundraising jeopardizes public trust, its reliance on rule of law is doubtful, and it dwarfs general acceptance of the outcome of the election, and genuineness of government so formed, as it gives room for the autonomy of the party in decision-making to be hijacked by political entrepreneurs. Once the strategic mechanism for orderliness is in place, democracy is seen as uniquely appropriate to provide a platform for salutary competition for power and influence. Biezen (2003) [19] notes that the most worrisome point at issue is that political parties' routine functions often create blurred view to dichotomize costs of its regular activities from campaign expenses. Party funds transcends campaign costs to embrace personnel emolument, cost of maintaining the party secretariat, its involvement in political education, voters registration exercise which is also paramount in democracy.

\section{Unregulated Political Party Fundraising}

In contemporary democracies, electorates are exhibiting increasing concern over the immodest financial influence on political decisions, and by extension, the link of corruption to politics. Besides, unbridled pattern of financing political activities breeds organized crimes, erodes transparency and accountability, and alienates the masses. As political parties are crucial element of pluralist democracies, their rapid loss of independence, the systemic destruction of democratic fabrics endangers the survival of young democracies in developing countries. For instance, Section 225(2) of the 1999 Constitution cited above does not deter lawless political parties from embarking on indecent fundraising. Political parties brazenly circumvented external auditing of the party accounts or adamant in flouting extant laws in respect of disclosing sources of money generated. This contravenes Section 93(1) but Section 93(2) which provides that "every political party shall keep an account and asset book into which shall be recorded all monetary and other forms of contribution received by the party; and the name and address of any person or entity that contributes any money or assets which exceeds N1,000,000.00. This provision contradicts Section 91(9) cited earlier, and gives political parties loophole to exceed the stipulated limit of donation.

Table 2 shows how People's Democratic Party (Obasanjo/Atiku) presidential campaign fundraising was ingloriously executed in 2003 election without recourse to extant law, and how individuals, faceless corporate bodies, foreign donors and anonymous donations brazenly contravened the rule of law and donated outrageously beyond the limit set by the electoral law. Also, James Ibori, Governor of Delta State in 2003 organized fundraising for campaign activities, which took the same lawless shape, and donations were limitlessly unregulated. Furthermore, Governor Bola Tinubu of Lagos State also organized fundraising for 2003 election; in the same vein, individuals and faceless friends contributed beyond the provisions of the subsisting Electoral Act. In 2015 presidential election, the President, Dr Good luck Jonathan grossly exceeded the limit for campaign donation and received billions of naira from faceless friends, individuals, groups and corporate bodies and against the Constitutional provision in Section 225(2), donors caught-in to donate extravagantly under the shield of Section 93(2) of the 2010 Electoral Act and no record of sources nor donors' names and addresses were kept for accountability. Ironically, the INEC did not moderate all these lawless fundraising for party campaigns nor sanction defaulters of the subsisting Electoral Act as provided by the extant law. A glaring case of ineffectiveness, ineptitude, naivety, and partisanship.

Table2. Donations to Political Aspirants in Fund Raising Campaign

\begin{tabular}{|l|l|c|c|}
\hline S/No & Name of Recipient & Amount (\#) & Material Gifts \\
\hline 1. & President Obasanjo/Atiku & $5,500,000,000.00$ & $\begin{array}{l}\text { 1 Boeing 727 } \\
\text { 4 Luxury Buses }\end{array}$ \\
\hline 2. & Governor James Ibori & $2,300,000,000.00$ & - \\
\hline 3. & Governor Bola Tinubu & $1,300,000,000.00$ & - \\
\hline 4. & Ghali Na'Abba & $150,000,000.00$ & - \\
\hline 5. & Governor Bukola Saraki & $160,000,000.00$ & - \\
\hline 6. & Governor Lucky Igbenedion & $500,000,000.00$ & - \\
\hline 7. & Great Ogboru & $200,000,000.00$ & - \\
\hline 8. & Chibodom Nwuche & $500,000,000.00$ & - \\
\hline
\end{tabular}

Source: Kura, S.Y.B. (2011). Political Parties and Democracy in Nigeria: Candidate Selection, Campaign and Party Financing in PDP. Journal of Sustainable Development in Africa, 13(6): 268-295.

Sourcing money for political party business beyond the approved limit has derailed politics and weakened the course of democracy in Nigeria. Excessive financing of political parties for their 
statutory functions and elaborate electioneering campaign programmes, and limitless expenses incurred in sponsoring candidates for elective public offices, have degenerated political parties to auction sales to the highest bidder among political entrepreneurs. The party is therefore being mortgaged as political collateral for the huge investments by the wealthier financiers of parties. Their gradual loss of autonomy is a serious and worrisome situation in Nigeria polity. Kura (2011) [20] observes that most of the donations were coming from individuals who were enjoying or potentially wanted to enjoy patronage from government. It was against the startling funding scenarios that the 2006 Electoral Act pegged individual donations to only N100,000.00. These reckless funding of parties breeds corruption, undermines transparency, accountability and responsiveness of party governments. Magolowondo et.al (2012) [21] note that money is an essential asset in politics, it can at the same time constitute danger if not well managed or regulated; money can provide opportunity for abuse by the governing party as they are in control of public assets.

The Electoral Act (as amended) in each election interval was enforced but it was not reinforced by the electoral umpire to regulate the unbridled reckless campaign donations and sanction culprits as appropriate. INEC was obviously overwhelmed by the magnitude of incredible donations recorded in all the campaign fundraising in the election periods. The institutional framework of the regulatory agencies is laid on weak structural foundation. The INEC is not independent, it lacks autonomy, competence and the audacity to probe into party financial transactions or incapability of the officials to indict those political juggernauts who appointed them into the positions of authority. Hence, its partisan disposition in favour of party in power, unavoidable enmeshment in election frauds, the strange and disturbing phenomenon of incessant inconclusive elections in polling units where election results are unexpected. The legislature on its part, as members of these political parties, and recipients of campaign donations, cannot carry out an oversight function on party financial transactions, else they shoot themselves on the leg. If INEC and the legislature cannot halt these social menace, in spite of the constitutional power reposed on them, who will?

\section{Ecological Factors Influencing Cost of Election Campaigns}

Nigeria polity does not operate in a vacuum, it is being operated within an environment which has adverse influence on electoral processes. Many sordid factors influence election campaigns in a corrupt terrain. Political scenario in Nigeria is volatile and money is the determinant factor on who wins election. Competence, integrity and reliability are the credentials of the poor candidates who are service-delivery oriented, and eager to offer good governance but cannot afford the attendant costs. Irrespective of its sources, money speaks louder than impeccable politicians, and the goats pursue the farmer with palm branches. The more you lavish resources thoughtlessly, the more followers you draw from the large hungry crowd. Some of the environmental factors are:

Media Campaigns: It has been recorded that the huge amount of money being invested in media campaigns through television advertisements, live coverage of political rallies, documentary coverage; radio advertisement/jingles, print media, giant billboards on strategic locations in cities and highways, and posters, to attract the attention of the public and as well appealing to their conscience for their support. The election campaign period is a very peak and lucrative season for media houses, and the prices for their services are highly increased. Individuals may, under the platform of a political party, desire to identify with the aspirants on the television or print media in form of canvassing for votes in favour of candidates of their choice, but in contravention of the law. Public and private media are being struggled for by all parties to dominate the airwaves, but party in government is somewhat monopolizing the public media. As observed by Olorunmola (n.d), [22] the 2015 presidential election media expenses of the two giant parties were higher than the amount required for the entire elections. Table 3 illustrates the enormity of funds set out for media campaigns alone in one election. The costs run counter to the provisions of the 2006/2010 Electoral Acts and the toothless law enforcement agency, despite its constitutional mandate to enforce compliance of the law, did not raise any eyebrow due to its moribund or regulatory agency's frailty. The system is characterized by feeble legal mechanisms.

Table3. Media Expenses for 2015 Presidential Election

\begin{tabular}{|l|c|c|}
\hline Description of Media Expenses & PDP Expense (\#) & APC Expenses ( $)$ \\
\hline Campaigns and Rallies & $1,280,374,879.00$ & $671,062,200.00$ \\
\hline Billboards & $473,160,000.00$ & $190,380,000.00$ \\
\hline Electronic Media Campaign & $532,100,000.00$ & $410,050,000.00$ \\
\hline
\end{tabular}




\begin{tabular}{|l|c|c|}
\hline \hline Electronic Media Advertisement & $3,988,822,125.00$ & $1,064,706,850.00$ \\
\hline Print Media Campaign & $2,475,228,301.00$ & $579,647,687.00$ \\
\hline Total & $\mathbf{8 , 7 4 9 , 6 8 5 , 3 0 5 . 0 0}$ & $\mathbf{2 , 9 1 5 , 8 4 6 , 7 3 7 . 0 0}$ \\
\hline
\end{tabular}

Source: Centre for Social Justice, 2015

Besides, in 2011 election, PDP expended $\$ 5,015,614,851.00$ on media campaign, while CAN, APGA and CPC spent N2,041,075,906.00 on the same purpose. PDP increased its media expenses in 2015 by $74.45 \%$ and the three opposition parties' media expenses together was increased by $42.86 \%$.

Weak Legal Mechanisms and Enforcement Capacity: The Electoral Act of 2002, 2006, 2010 were enacted to introduce sanity in the polity as an improvement on the legal provisions of the 1979 and 1999 Constitutions to regulate campaign financing. The old law provides for budgetary allocations for annual grants to political parties; allowed parties to receive donations from individuals and corporate organizations, but prohibited donations from foreign bodies. Howbeit, no limit was placed on the amount of money individual candidates or political parties could receive from donors. The legal framework was porous for politicians to abuse. Political entrepreneurs immoderately donated to candidates and parties, and profoundly funded campaigns as business investment ventures. These reckless donations breed plutocracy, organized crimes and crude manner of recouping the money invested. Corruption was unbridled and tenets of democracy were perverted and compromised. Political parties and candidates are accountable to those donors who financed their campaign expenses than to their respective constituents. This constitutes serious threat to the economic growth, political stability, and development of democracy.

The subsisting law that guided 2003, 2007, 2011 and 2015 elections has gone through series of amendments to strengthen its content in keeping with realities. The law assigns INEC with the responsibility to register and regulate party activities, superintend over party primary elections, and to exercise oversight functions over all financial transactions of all political parties. This instrument has been poorly enforced. The regulatory agency is overwhelmingly weak to reinforce the law, it lacks enforcement capacity to arraign those who have breached the law, incompetent to moderate party financing and campaign donations, and partisan in implementing the clauses of the Act that deals with defaulting cases. The provisions of the Electoral Act have been grossly variously violated by political parties and individual candidates as shown in tables 2 to 3 above, yet there has been no investigation, arrest or prosecution of defaulters for contravening the law.

Cost of Party Nomination Form: Indication of interest to contend for elective positions in political party primaries is seen as a serious business, and interested party members are expected by the Party Constitution to express commitment in monetary term, so as to qualify for picking nomination form. Inasmuch as the exercise is an internal process of generating funds for political party activities, the costs of expression of interest and obtaining the nomination form should not only be made to be moderate, but must be seen publicly to be temperate to ensure inclusiveness in participation. The costs of indication of willingness and subsequent purchase of nomination form have no direct bearing to what constitutes the spending limit in elections. This exercise is patterned exclusively for the rich due to the high cost of these requirements, and to skew the poor and the moderates out of the race. Most often, prospective candidates mortgage their assets, obtain loan facility from the banks or sell their properties to contest in an election. Oladimeji (2014) cited in Olorunmola (n.d) [23] notes that in 2015 general election, All Progressive Congress (APC) presidential candidates had to pay two million, five hundred thousand naira $(\$ 2,500,000.00)$ to indicate interest; and twenty-five million naira ( $\$ 25,000,000.00$ ) for obtaining the form. The prospective presidential candidates in the People's Democratic Party (PDP) were required to remit two million naira (N2,000,000.00) for expression of interest, and twenty million naira $(\mathrm{N} 20,000,000.00)$ for the purchase of the nomination form. All Progressive Grand Alliance (APGA) did not fill candidate for presidential election. The requirements for other categories of aspirants are illustrated in table 4.

Table4. Cost of Aspirants' Expression of Interest and Nomination Form

\begin{tabular}{|c|c|c|c|c|}
\hline Party & Office in View & $\begin{array}{l}\text { Expression of } \\
\text { Interest (\#) }\end{array}$ & $\begin{array}{c}\text { Nomination Fee } \\
(\#)\end{array}$ & Total $(\#)$ \\
\hline \multirow[t]{3}{*}{ APC } & Presidency & $2,500,000.00$ & $25,000,000.00$ & $27,500,000.00$ \\
\hline & Governorship & $500,000.00$ & $5,000,000.00$ & $5,500,000.00$ \\
\hline & Senate & $300,000.00$ & $3,000,000.00$ & $3,300,000.00$ \\
\hline
\end{tabular}


Political Party Financing and Consolidation of Democracy in Nigeria, 1999 - 2015

\begin{tabular}{|l|l|r|r|r|}
\hline \hline & House of Rep & $200,000.00$ & $2,000,000.00$ & $2,200,000.00$ \\
\hline \multirow{4}{*}{ PDP } & Presidency & $2,000,000.00$ & $20,000,000.00$ & $22,000,000.00$ \\
\cline { 2 - 5 } & Governorship & $1,000,000.00$ & $10,000,000.00$ & $11,000,000.00$ \\
\cline { 2 - 5 } & Senate & $500,000.00$ & $4,000,000.00$ & $4,500,000.00$ \\
\cline { 2 - 5 } & House of Rep & $400,000.00$ & $2,000,000.00$ & $2,400,000.00$ \\
\hline \multirow{4}{*}{ APGA } & Presidency & - & - & - \\
\cline { 2 - 5 } & Governorship & $2,000,000.00$ & $10,000,000.00$ & $12,000,000.00$ \\
\cline { 2 - 5 } & Senate & $500,000.00$ & $3,000,000.00$ & $3,500,000.00$ \\
\cline { 2 - 5 } & House of Rep & $500,000.00$ & $2,000,000.00$ & $2,500,000.00$ \\
\hline
\end{tabular}

Source: Olorunmola, A. (nd). Cost of Politics in Nigeria http://www.wfd.org/wp-content/uploads/2016/07/ Nigeria-Cost-of-Politics.pdf

Godfatherism Extortion: Most prospective candidates lack self-confidence, courage, resources, and charisma to woo the public support on their sides. Aspirants heavily rely on the support and sponsorship of political entrepreneurs known as godfathers. Some wealthy candidates struggle profusely with much incentives to win the 'blessings' of godfathers to support their candidatures. The syndrome of godfatherism raised its ugly head more pronouncedly in the fourth republic. Prior to this era, political tutelage and apprenticeship were on board, where the novice learn the art of governance from experienced professionals in the skills of politics and governance. This sacred practice has been sacrificed and monetized in the new political dispensation. These godfathers wield ruthless powers to direct the political compass and freely impose candidates on electorates and ensure victory of such favoured 'puppets' at the poll. In return, such planted elements in public appointive or elective offices and the parliament metamorphosed to conduit-pipes to siphon public resources at the desires of the godfather. Most godfathers shoulder the election expenses, also be instrumental to the emergence of virtually all successful candidates in their respective state of operation through mobilization of support, finance, thuggery and violence to ensure success of the candidates at the polls. It is always ado-or-die affair, a survival of the fittest battle, and zero-sum-game politics.

This political corruption has destroyed the fabrics of democracy in Nigeria. For instance, Human Rights Watch (2007), cited in Olorunmola (n.d), [24] notes that Alhaji Olusola Saraki reigned as godfather in Kwara State and mostly single-handedly determined who emerged for federal and state elections from the state. Late Chief Lamidi Adedibu of Oyo State boasted in public forum to have single handedly sponsored every successful politician in the state, including the governor, federal and state legislators. Winning the support of godfathers for election purposes is a crude and unkind gesture, exploitative and expensive adventure. The shylock political entrepreneurs often demand prepayment for their services or ritual commitments for regular returns of a certain percentage of annual state budget or fixed amount of money to recoup their investments. If the recipients renege on the contracts after victory, the godfathers would do all within their powers to put the recalcitrant subordinates on their heels, making the state ungovernable or cause the impeachment of the officer. For example, Governor Chinweoke Mbadinuju of Anambra State had the wrath of his godfather, Chief Emeka Offor when he reneged on the terms of contract. He did not return for a second tenure. In 2003, Governor Chris Ngige of Anambra State attracted the wrath of his godfather, Christ Uba when he also reneged on the terms of agreement after victory. Further, the impeachment of Governor Rashidi Ladoja of Oyo State in 2006 was masterminded and facilitated by his godfather, late Alhaji Lamidi Adedibu, as penalty for refusing to remit the agreed N15, 000,000.00 monthly from the state security budget (Olorunmola, n.d). [25] Godfatherism is a political scrounge, anti-people oriented, and an aberration of democracy.

Party Primary Extortion: Under the legal framework guiding the electoral processes, political parties have the legal responsibility to organize party primaries, under the superintendent of the INEC, to elect their party officials, and candidates for various elective offices. This intra-party exercise has been transformed to illegal and extortive business venture, where delegates and party officials transact illicit deals to exploit candidates since the success of the aspirants is determined by the votes of the delegates. Invariably, the delegates are the political bride, the candidates and their sponsors resort to bargaining effectively to purchase the delegates' votes, and offer bribes to woo the party officials. Every aspirant with his/her sponsor adopts any viable strategy to garner massive support amongst the delegates. Some may resort to accommodating the delegates in secret locations to keep them incommunicado from other candidates. Others may intimidate their rivals with large quantum of money being offered to each delegate to influence their sense of judgment. These delegates are 
loyalists of the aspirants in their respective localities, whose sponsorship elevated them to party executive positions to become delegates. At the convention arena, the highest bidder (not benefactors) have the votes, yet they receive money from all the individual aspirants. Onyekpere (2015)[26] observes that for over 8,000 delegates of APC presidential primary in Lagos State were allegedly paid US $\$ 5,000$ each from the two candidates (Atiku Abubakar US $\$ 2,000$; Mohammadu Buhari US $\$ 3,000$ ) for presidential race. This sum excludes monetary bribes, free hotel accommodation and attendant charges on feeding, drinks, and transportation for the three-day convention. In spite of this huddle, the exercise is fraught with irregularities, electoral fraud in favour of the predetermined candidates. These are few of the major factors escalating campaign expenses in Nigeria.

\section{RESULTS AND DisCuSSION}

Political instability in the country is as a result of absence of intra-party democracy and lack of rule of law. Credibility of electoral processes is doubtful as INEC is partisan, incompetent, and lacks autonomy to enforce the extant electoral law governing party primaries, party funding, and electioneering campaign expenses. Smith (1995) [27] argues that effort to limit political contributions and spending are extremely popular, yet there is no serious evidence that campaign finance regulation has achieved or will achieve its goal of reducing the influence of money, opening up the political system, and lowering the cost of campaigns. Finance has constituted serious threat to survival of democracy in Nigeria as money is being used recklessly to influence party primaries, election results, and government policies. Efforts to limit contributions and spending have been based on faulty assumptions. The destiny of the nation is being mortgaged as a collateral into the hands of political investors. The infiltration of foreign donors in political party financing and campaign expenses has exacerbated the precarious political situation of the country. Gardner (cited in Smith, 1995) [28] notes that there is nothing in our political system today that creates more mischief, more corruption, and more alienation and distrust on the part of the pubic than does our system of financing elections. The study indicates that such ungodly donations breeds organized crimes and political corruption.

The short sightedness of the political class has plunged the nation into economic recession, bad governance and the common people are suffering the deficit of democracy. Nigerians are experiencing galloping inflation, rapid devaluation of its currency, stunted economic growth, and high poverty rate. There is increase in crime rate, unemployment, high insecurity rate. Efforts to regulate campaign finance have been disastrous. They have distorted the political process, hindered grassroots political involvement, infringed on electorates rights, and helped to entrench incumbents in office while doing nothing to address the allegedly corrupting influence of money in politics. Illegal fundraising increases the gap between political elites and ordinary citizens. If political parties and candidates do not depend on their supporters or members neither for fund contributions nor for voluntary labour, they might be less likely to involve them in party decisions or consult their opinion on policy issues.

\section{CONCLuSION}

Democracy is dysfunctional without political parties and elections to determine, through the choice of the people, who runs the affairs of government within a timeframe. Political parties cannot survive without sufficient funds to execute their numerous functions. Illegal fundraising, reckless and lawless donations from political entrepreneurs have debased democracy and constitute finance as dangerous threat for the survival of democracy. In any society infested with corrupt practices, the corrupt elements flourish to the detriment of the society if not regulated. The weaknesses of the regulatory authority to reinforce the extant law on political party financing and incapacity of the agency to sanction defaulters who breached the fundraising limits for electioneering campaigns and party activities invigorates corruption. The horrible situation is exacerbated by the activities of the party in government, which incapacitates regulatory authority. The state resources is being abused by the ruling party in its efforts to reposition itself advantageously to the detriment of the governed. The lack of synergy and equal level playing field prohibits equal participation and representation of all citizens in democratic processes. The growing infiltration of foreign organized crime through illicit funds into politics adversely influence campaign financing and party activities. The blurred electoral finance and absence of transparency and lack of oversight functions are affording opportunities for organized crime to gain undue influence over elected officials by financing their campaigns. These defects undermine the growth of democracy, compromise rule of law, political stability, as well as having unfavourable consequences for economic development and wellbeing of the society. 


\section{REFERENCES}

Cole, P., Nigeria: Financing political parties, elections and corruption, (2016). Accessed from http://allafrica.com/stories/201603090833.html (July 29 2016).

INEC and challenges of monitoring political party campaign financing in Nigeria, (2015).

Accessed from: http://nairaproject.com/projects/923.html (August 20 2016).

Political party funding. Accessed from: http://en.wikipedia.org/wiki/political-party-funding (July 25 2016).

Magolowondo, A., Falguera, E. and Matsimbe Z., Regulating political party financing: Some insights from the praxis. Netherland: Institute for Multiparty Democracy/International Institute for Democracy and Electoral Assistance (2012). (A study).

Ali, A., Conducting research in education and the social sciences, $1^{\text {st }}$ ed. Enugu: Tashiwaa Networks Ltd., (2006), ch.9, pp.255-271.

Nworgu, B.G. Educational Research: Basic Issues and Methodology. ( $2^{\text {nd }}$ ed.)Enugu: University

Trust Publishers, (2006), ch.5, pp.67-83.

Umar, M.Z. Qualitative research method: Insights and perspectives on data collection and content analysis. In A.M. Okolie and O.G. Ajene (eds.) Research methodology in social science analysis, $1^{\text {st }}$ ed. Enugu: Nigerian Political Science Association, 2016, ch.9, pp. 127-136.

'Elite: Identity and social structure' Accessed from: http://en.wikipedia.org/wiki/Elite (December 5 2015).

Freeman, Jo, 'The Tyranny of Structurelessness'. Berkeley Journal of Sociology, 17, 151-164 (1972).

Varma, S. P., 'Modern political theory'. (2 $2^{\text {nd }}$ ed.) New Delhi: Vikas Publishing House PVT Ltd,

(2006), ch. 5, pp.143-161

'Elite theory' Accessed from: http://en.wikipadia.org/wiki/Elite_theory\#Classical_ elite_ theorists (November 82015 ).

Elite. Accessed from: http://en.wikipedia.org/wiki/Elite (October 24 2016).

Ballington, J. et al Funding and political parties and election campaigns: a handbook on political finance. International Institute for Democracy and Electoral Assistance, Sweden, (2014), Accessed from: http://funding-of-political-parties-and-election-campaigns-a-handbook-onpolitical-PDF-pd (August 30 2016).

FRN, Re-enactment of electoral act and Independent National Electoral Commission, to regulate

the conduct of federal, state, and area council elections and for related matters. Abuja: Government Press, (2010), ch.5, pp.19-31.

Ibid [4]

FRN, Constitution of the Federal Republic of Nigeria (promulgation) decree No. 24. Abuja: Government Press, (1999), ch.6, pp.115-118.

FRN, Re-enactment of electoral act and Independent National Electoral Commission, to regulate

the conduct of federal, state, and area council elections and for related matters. Abuja: Government Press, (2010), ch.5, pp.19-31.

Biezen, I.V., Financing political parties and election campaigning - guidelines.

Germany: Council of Europe, (2003), Accessed from: https://eos.cartercenter.org/uploads/ document_file/path/309/Financing_Political_Parties_en.pdf (October 23 2016).

Kura, S.Y.B., Political parties and democracy in Nigeria: Candidate selection, campaign and party financing in PDP. Journal of Sustainable Development in Africa, 13(6):268-295, (2011).

Ibid [4]

INEC and challenges of monitoring political party campaign financing in Nigeria, (2015).

Accessed from: http://nairaproject.com/projects/923.html (August 04, 2016)

Olorunmola, A., Cost of Politics in Nigeria, (nd). Accessed from http://www.wfd.org/wpcontent/uploads/2016/07/Nigeria-Cost-of-Politics.pdf(28/9/2016).

Ibid [23]

Ibid [23] 
Onyekpere, E., Still above the ceiling: A report on campaign finance and use of state administrative resources in the 2015 election. Abuja: Centre for Social Justice, (2015).

Smith, B.A. Campaign finance regulation: Faulty assumptions and undemocratic consequences, (1995). Accessed from: www.cato.org/pubs/pas/pa238.html (October 29, 2016).

Ibid [27] 